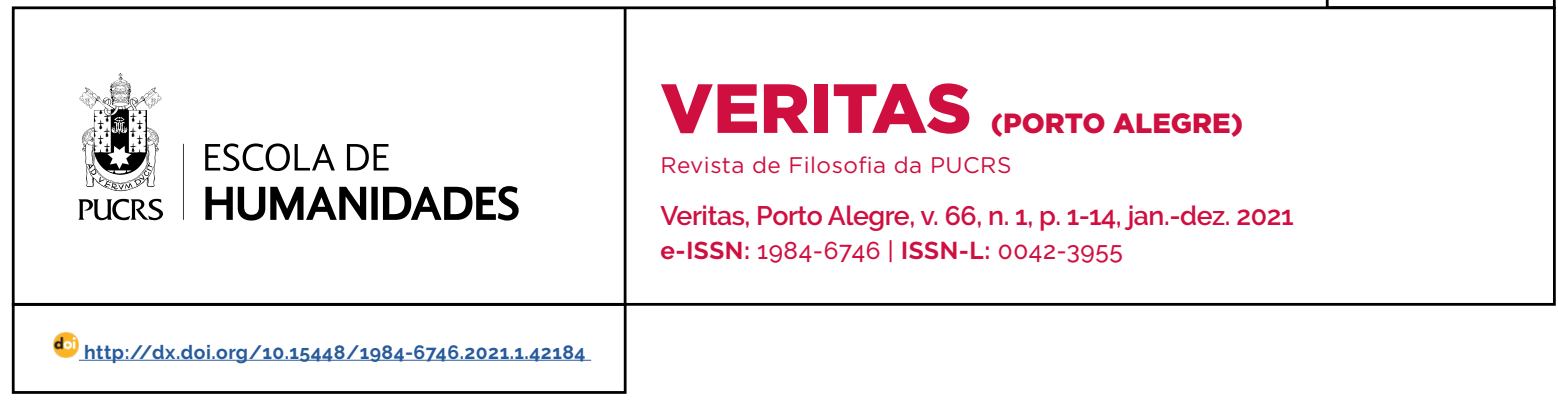

EPISTEMOLOGY \& PHILOSOPHY OF LANGUAGE

\title{
Neo-Pyrrhonism, Empiricism, and Scientific Activity
}

\author{
Neopirronismo, Empirismo e Atividade Cientitica \\ Neopirronismo, Empirismo y Actividad Cientifica
}

\section{Otávio Bueno ${ }^{1}$}

orcid.org/0000-0002-9161-4205

otaviobueno@mac.com

Recebido em: 11 nov. 2021.

Aprovado em: 15 nov. 2021.

Publicado em: 27 dez. 2021.

\section{(c) (1)}

Artigo está licenciado sob forma de uma licença Creative Commons Atribuição 4.0 Internacional.
Abstract: Pyrrhonism involves the inability to defend claims about the unobservable world, or, more generally, about what is really going on beyond the phenomena (SEXTUS EMPIRICUS, 1994). As a result, the Pyrrhonist is not engaged in developing a philosophical doctrine, at least in the sense of defending a view about the underlying features of reality. The issue then arises as to whether the Pyrrhonist also has something positive to say about our knowledge of the world, while still keeping Pyrrhonism. In this paper, I develop a positive neo-Pyrrhonist attitude, indicating that we can use this attitude to make sense of important aspects of science and empirical knowledge. To do that, I explore the connection between this revived form of Pyrrhonism and contemporary versions of empiricism, in particular constructive empiricism (VAN FRAASSEN, 1980, 1989, 2002, 2008). Although constructive empiricism is not a form of skepticism, there are important elements in common between constructive empiricism and Pyrrhonism. The resulting form of Pyrrhonism suggests that there is something right about the original stance articulated by Sextus Empiricus, and that suitably formulated it provides an insightful approach to think about empirical knowledge (PORCHAT PEREIRA, 2006, for the original inspiration behind neoPyrrhonism).

Keywords: Pyrrhonism. Empiricism. Scientific activity. Empirical knowledge. van Fraassen.

Resumo: O pirronismo envolve a incapacidade de defender afirmações sobre o mundo inobservável, ou, mais geralmente, sobre o que realmente está acontecendo além dos fenômenos (SEXTUS EMPIRICUS, 1994). Como resultado, o pirrônico não está empenhado em desenvolver uma doutrina filosófica, pelo menos no sentido de defender uma doutrina sobre as caracteristicas subjacentes da realidade. Surge então a questão de se saber se o pirrônico também possui algo positivo a dizer sobre nosso conhecimento do mundo, mantendo ainda o pirronismo. Neste artigo, desenvolvo uma atitude neopirrônica positiva, sugerindo que podemos usar essa atitude para dar sentido a aspectos importantes da ciência e do conhecimento empírico. Para tanto, exploro a conexão entre esta forma revivida de pirronismo e versões contemporâneas do empirismo, em particular o empirismo construtivo (VAN FRAASSEN, 1980, 1989, 2002, 2008). Embora o empirismo construtivo não seja uma forma de ceticismo, existem elementos importantes em comum entre o empirismo construtivo e o pirronismo. A forma resultante de pirronismo sugere que há algo correto sobre a postura original articulada por Sexto Empírico e que, adequadamente formulada, ela fornece uma abordagem perspicaz para se refletir sobre o conhecimento empírico (PORCHAT PEREIRA, 2006, para a inspiração original por trás do neopirronismo).

Palavras-chave: Pirronismo. Empirismo. Atividade científica. Conhecimento empírico. van Fraassen. 
Resumen: El pirronismo implica la incapacidad de defender afirmaciones sobre el mundo inobservable o, más en general, sobre lo que realmente está sucediendo más allá de los fenómenos (SEXTUS EMPIRICUS, 1994). Como resultado, el pirrónico no se dedica a desarrollar una doctrina filosófica, al menos en el sentido de defender una visión sobre las caracteristicas subyacentes de la realidad. Se plantea entonces la cuestión de si el pirrónico también tiene algo positivo que decir sobre nuestro conocimiento del mundo, manteniendo todavia el pirronismo. En este artículo, desarrollo una actitud neopirronista positiva, lo que indica que podemos usar esta actitud para dar sentido a aspectos importantes de la ciencia y el conocimiento empírico. Para ello, exploro la conexión entre esta forma revivida de pirronismo y las versiones contemporáneas del empirismo, en particular el empirismo constructivo (VAN FRAASSEN, 1980, 1989, 2002 , 2008). Aunque el empirismo constructivo no es una forma de escepticismo, hay elementos importantes en común entre el empirismo constructivo y el pirronismo. La forma resultante de pirronismo sugiere que hay algo correcto en la postura original articulada por Sextus Empiricus, y que adecuadamente formulada proporciona un enfoque perspicaz para pensar sobre el conocimiento empírico (PORCHAT PEREIRA, 2006, para la inspiración original detrás del neopirronismo).

Palabras clave: Pirronismo. Empirismo. Actividad científica. Conocimiento empírico. van Fraassen.

To the memory of Oswaldo Porchat, teacher and friend.

\section{Introduction}

There are significant connections between skepticism and scientific practice. Some aspects of scientific reasoning and practice may not seem to be particularly skeptical3/4in fact some may even seem to go against skepticism. But it turns out that both in the development of new theories and in the design and implementation of experiments, there is a special role for skeptical considerations. What sense of 'skeptical' is at stake here? I think a very definite answer can be given in terms of Pyrrhonism. In this paper, I will adopt what I take to be the most interesting, and the only coherent, skeptical approach3/4Pyrrhonism $3 / 4$ to indicate what bearing it has on several aspects of contemporary scientific practice.

Most forms of skepticism $3 / 4$ and I have in mind here, in particular, Cartesian skepticism3/4are introduced so that it can be shown why they are wrong. Epistemology then becomes, in part, the development of strategies to refute the skeptic. Not that there are Cartesian skeptics around.
If skepticism is the claim that nothing can be known $3 / 4$ arguably an implausible and self-refuting view $3 / 4$ hardly anyone does in fact endorse skepticism. In this formulation, skepticism is a form of dogmatism, albeit a negative one, given that a view about the impossibility of knowledge is advocated. Clearly it does not seem to offer a very illuminating account of knowledge.

The situation is very different, however, with Pyrrhonism. First of all, as is well known, Pyrrhonism is not $3 / 4$ and should not be thought of as $3 / 4 a$ philosophical doctrine, that is, a set of philosophical beliefs. Rather it is a particular attitude, a stance. As Sextus Empiricus points out:

Skepticism is an ability to set out oppositions
among things which appear and are thought of
in any way at all, an ability by which, because of
the equipollence in the opposed objects and
accounts, we come first to suspension of ju-
dgment and afterwards to tranquility. (SEXTUS
EMPIRICUS, 1994, p. 8; PH 1: 8; italics added.)

As Sextus insists, Pyrrhonism is a particular ability, a particular attitude of investigation: the ability to oppose appearances and objects of thought, as a way of trying to determine which things (if any) the skeptic should assent to. However, since "to every account an equal account is opposed" (SEXTUS EMPIRICUS, 1994, p. 12; PH 1: 12), and since these opposed accounts are equally persuasive to the skeptic, the latter is unable to decide between them, and suspends judgment. As a result, the Pyrrhonist ends up holding no beliefs about the underlying features $3 / 4$ or the true nature $3 / 4$ of the phenomena.

In other words, Pyrrhonism involves an inability to defend claims about the unobservable world, or, more generally, about what is really going on underlying the appearances (see SEXTUS EMPIRICUS, 1994). In fact, the Pyrrhonist is not in the business of developing a philosophical doctrine, at least in the sense of defending a view about the ultimate features of reality. This emerges from the Pyrrhonist's strategy of investigation. He or she first examines critically the views of dogmatic philosophers $3 / 4$ who defend claims about the worl$\mathrm{d}^{3} / 4$ and contrasts equally persuasive arguments for and against such claims. Being unable to decide 
among such arguments, the Pyrrhonist suspends judgment, and (rather unexpectedly) obtains tranquility. This provides the first part of the Pyrrhonist's negative or critical assessment of dogmatic views: dogmatists seem to embrace their views without due consideration to rival alternatives.

The second, and more direct, part of the negative assessment of dogmatism is given by the use of Agrippa's modes3/4hypothesis, circularity, and infinite regress (SEXTUS EMPIRICUS, 1994, pp. 4043; $P H$ 1: 15). With these modes the Pyrrhonist has a strategy to make explicit that, according to the standards embraced by dogmatic philosophers, the latter seem to be unable to assent to their own doctrines. In outline, the well-known strategy is this: To begin with, the Pyrrhonist points out that there is disagreement regarding the true nature of a given subject. In order to try to settle the disagreement, the dogmatic philosopher cannot simply assert without argument his or her view about the issue; otherwise, someone could just as easily assert, also without argument, the negation of the dogmatist's claim. Clearly, none of these maneuvers would be persuasive (hypothesis). Moreover, in order to support his or her view, the dogmatic philosopher cannot offer a reason that presupposes the truth of that view, given that such a reasoning would be blatantly circular (circularity). This means that the dogmatic philosopher needs to offer reasons that are independent of the view he or she is trying to defend. But these reasons cannot just be asserted without justification $3 / 4$ otherwise, one could simply assert the negation of these reasons. In other words, the reasons in question also need to be justified by other reasons. The new reasons, in turn, similarly need to be supported, and this yields an infinite regress of reasons (infinite regress). (For a detailed and provocative critical discussion of this argumentative strategy, see BARNES, 1990; for a critique of some of Barnes's claims, see BUENO, 2013a. Two important new reassessments of Pyrrhonism are offered in MACHUCA, 2022, and SMITH, 2022.)

Given the negative component of Pyrrhonism, does the Pyrrhonist have something positive to say about knowledge $3 / 4$ while still keeping his or her skeptical stance? In this paper, I sketch a positive Pyrrhonist attitude, indicating that we can use this attitude to make sense of some aspects of scientific activity and of empirical knowledge. In fact, I will explore a neo-Pyrrhonian strategy of investigation, in the sense that it is inspired by Pyrrhonism, and should be compatible with it, although it will go beyond Sextus' writings in various ways. The approach is inspired by the highly original interpretation of Pyrrhonism advanced by Oswaldo PORCHAT PEREIRA, 2006. (Critical examinations of Porchat's neo-Pyrrhonism are offered in SMITH (ed.), 2014, and SMITH, 2017; for a different form of neo-Pyrrhonism, see FOGELIN, 1993.) As will become clear, this paper pursues the avenue opened up by Porchat with neo-Pyrrhonism.

To do that, I explore the connection between this revived form of Pyrrhonism and contemporary versions of empiricism, in particular constructive empiricism (VAN FRAASSEN, 1980 and 1989; see also VAN FRAASSEN, 2002 and 2008). Although constructive empiricism is not a form of skepticism, there are important elements in common between constructive empiricism and Pyrrhonism; in particular, the emphasis on the observable aspects of the world, the idea that truth need not be a norm for (scientific) inquiry, and the use of underdetermination arguments to motivate agnosticism about the existence of unobservable entities. I will also indicate significant differences between neo-Pyrrhonism and constructive empiricism

This revived form of Pyrrhonism indicates that there was something right with the original stance articulated by Sextus Empiricus, and that, suitably formulated, it provides a novel way to examine empirical knowledge. Throughout this paper, I use '(neo-) Pyrrhonism' and 'skepticism' as synonymous. If I intend to refer to some other form of skepticism, I will employ suitable qualifiers, such as 'Cartesian skepticism'.

\section{The neo-pyrrhonian attitude}

Before becoming skeptics, "men of talent" initially thought that by searching for the truth, they could attain tranquility. And to find the truth, they examined various proposals about the true 
nature of things. What they found out, however, were deep disagreements about every issue under consideration, and due to the equal force (equipollence) of the arguments put forward by those involved in the debates, these men of talent were unable to decide between the various views. As a result, they were led to suspend judgment about the issues at hand, and to their great surprise, they obtained tranquility (see SEXTUS EMPIRICUS, 1994, pp. 4-6; PH 1: 4-6). In outline, this is the description that Sextus offers of how some have become Pyrrhonists. Whether this is the description of an actual event, or simply an idealized narrative, it offers significant insights into some features of the skeptical style of investigation.

First, in broad brushstrokes, we have here the steps of the skeptical inquiry: (a) an initial search for the truth about a certain question; (b) the realization of the deep disagreement among scholars about what the correct answer is regarding that question; (c) the equipollence of the various arguments that are offered on each side of the question, and the resulting impossibility of deciding between such arguments; (e) the suspension of judgment on the part of the skeptic, and ( $f$ ) the skeptic's emerging tranquility. The outcome of this style of inquiry is that the skeptic is condemned to investigate the issues endlessly: skeptical inquiry is continuous and never-ending. After all, if the skeptic ever stopped the inquiry, thus presumably settling on some claim or another, or if the skeptic no longer explored the issues any further, he or she would cease to be a skeptic and become a dogmatist.

What if skeptics simply stopped doing philosophy altogether, and became, say, professional runners? To the extent that runners make claims about the nature of things (say, about the nature of running, the difference between running and jogging, and so on), they obviously would no longer be skeptics. If runners refuse to make such claims, not as the outcome of an inquiry that motivates suspension of judgment, but out of simple stubbornness, they will not be skeptics either, given the adoption of a dogmatic attitude toward the potential outcome of a skeptical mode of inquiry.

Given the repeated failed attempts to find the truth, do skeptics eventually give up on the search for truth? In a certain respect, they do; in another, they don't. On the one hand, establishing the truth is no longer taken to be an aim of inquiry. At least it is not an aim that skeptics expect to realize in case it ever is achieved. After all, it is unclear how skeptics can be in a position to know that the truth has been found. On the other hand, as just noted, skeptical inquiry will never stop $3 / 40$ n pain of turning skeptics into dogmatists. So, it is possible that the truth is eventually found, even though skeptics are unable to know whether that has in fact happened.

Here are then two central features of skeptical inquiry. First, it is a non-dogmatic inquiry. The goal is no longer to establish the truth; that is what dogmatic philosophers were unsuccessfully trying to achieve. The goal is also not to establish the impossibility of establishing the truth, given that this would simply amount to a negative form of dogmatism. Second, skeptical inquiry is an endless form of investigation. As we saw, skeptics will have to be continuously searching, investigating, comparing, and assessing various arguments and views.

Throughout the Pyrrhonists' investigation, underdetermination arguments play a crucial role. In fact, skeptics use these arguments to challenge dogmatists' claims to the effect that it is possible to know the nature of those unobservable entities that are postulated in science and (to some extent) in ordinary life. After all, given that the same phenomena can be yielded by radically different unobservable objects, it is unclear how one can decide what is really going on beyond the appearances (see SEXTUS EMPIRICUS, 1994). For instance, do souls exist? It may be argued that bodily movements provide evidence for the existence of the soul (for a discussion, see, e.g., SEXTUS EMPIRICUS, 1994, pp. 75-76, 93; PH 2: 5. 10), given that the presence of the latter would account for the possibility of the former. But bodily movements can also be explained independently 
of the postulation of souls. Such movements may be the result of other bodily movements (all the way down to certain chemical processes in the brain). Thus, the same phenomenon (bodily movements) can be explained by invoking radically different unobservable objects (souls or chemical processes). How can one decide what is really going on?

It may be argued that positing chemical processes in the brain offers a better explanation of the source of bodily movements than the postulation of souls, and hence this hypothesis is more likely to be true. Let us grant that the chemical processes hypothesis provides a better explanation of the phenomenon in question than the postulation of souls. What is problematic in this argument, however, is the underlying inference to the best explanation. From the fact that a certain hypothesis offers a better explanation than its rivals, it does not follow that the hypothesis in question is thereby more likely to be true. After all, the various explanations under consideration may all be false (see VAN FRAASSEN, 1989).

Let us consider a more contemporary example. Quantum phenomena can be explained in terms of particles for which it is not possible to determine their position and momentum simultaneously with full certainty, as the Copenhagen interpretation has it. But the same phenomena can also be explained in terms of particles for which it is possible to determine their position and momentum simultaneously $3 / 4$ provided that there is a quantum potential, as is advanced by the Bohmian interpretation. Given the fundamental difference about the nature of quantum particles involved here, and the fact that such interpretations are equally adequate to accommodate the empirical phenomena, it is unclear how one can choose between them on just empirical grounds. Once again, due to the resulting underdetermination, it is unclear how to decide what is really going on beyond the phenomena.

Underdetermination arguments are closely related to a form of argument that Sextus discusses in detail: arguments from relativity (see, e.g., SEXTUS EMPIRICUS, 1994, pp. 12-40; PH 1:
14). The crucial feature of these arguments is that the same objects produce different appearances in different circumstances. Thus, it is unclear what the true nature of these objects ultimately is. Consider, for instance, the nature of honey (see, e.g., SEXTUS EMPIRICUS, 1994, p. 28; PH 1: 14). Honey seems to be sweet to those who are healthy, and bitter to those who have jaundice. Is honey, in the end, sweet then? Based on our experience of it, and the way honey changes in changing circumstances, it is unclear how the issue could be decided.

In a certain way, arguments from relativity are dual to underdetermination arguments. The latter indicate that the same phenomena can be the product of different underlying unobservable features, whereas the former indicate that the same (observable) objects can yield different phenomena (in changing situations). Both arguments can be used to produce suspension of judgment about knowledge of the true nature of things $3 / 4$ whether we are considering observable objects (in the case of arguments from relativity) or unobservable entities (in the case of underdetermination arguments).

Skeptics only follow what appears to them $3 / 4$ that is, the phenomena. And skeptics use the phenomena as a guide to inquiry (and to life more generally) in the sense that the phenomena shape the skeptics' experience and help to structure central questions that are addressed throughout their investigation. What are the underlying causes of the phenomena? Can we decide what their true nature is? Are there things that exist beyond the phenomena? If so, how can we know them? Although skeptics follow the phenomena, they need not follow them uncritically, since, as we saw in the case of the taste of honey, disagreement can emerge among the phenomena themselves. Given such disagreement, skeptics will suspend judgment about the true nature of the objects in question $3 / 4$ even observable objects. Clearly, by simply following the appearances, skeptics do not settle the ontological issue regarding the nature of things. After all, no commitment to any specific answer to that issue is involved, given that (i) the 
same appearances are compatible with radically different answers to the ontological issue, and (ii) skeptics simply report on what seems to them to be the case, rather than assert what is really going on. Note also that skeptical investigation does not require that questions about the nature of objects be decided. One may be led to suspend judgment about such issues as the result of the investigation.

This is the reason why skeptics can be described as not having beliefs (in particular, about the true nature of things), given that they only report on the appearances and, thus, only on what seems to be the case. Of course, skeptics may end up making true claims about appearances. But given that appearances are not taken to be true reports on the nature of things, given the possible disagreement among the appearances, no true claims about the ultimate features of reality emerge. Moreover, beliefs are not needed to conduct and develop skeptical research. Skeptics explore various possible explanations, such as those advanced by dogmatic philosophers, indicating how each explanation suggests a way the world could be. This is a non-dogmatic form of research since the truth of the various explanations is never asserted: they are often underdetermined by the available evidence. Moreover, by exploring the various conceptual possibilities offered by dogmatists' views, skeptics can indicate how each of them gives us understanding $3 / 4$ particularly, of the way things could be. Such explanations, as will become clear shortly, play a similar role played by various interpretations of quantum mechanics in the context of constructive empiricism (see VAN FRAASSEN, 1989 and 1991).

Thus, the neo-Pyrrhonian approach emphasizes negatively not only the harshness of dogmatists' commitments and knowledge claims about the unobservable, but also, more positively, the significant source of understanding that the various hypotheses about unobservable entities provide. This is an aspect of neo-Pyrrhonism that clearly goes beyond what Sextus has explicitly articulated. It is not obvious that Sextus would have much sympathy for this sort of concession to dogmatic philosophy, namely, that it offers understanding of the possibilities for what goes on beyond the appearances. Sextus' main emphasis has been on the negative aspect of Pyrrhonis$\mathrm{m}^{3} / 4$ the critical scrutiny it provides of the various dogmatic philosophical doctrines.

However, as part of a more positive neo-Pyrrhonism, one could perfectly well concede that each dogmatic philosophy offers a certain conception (a certain "picture") of how the world could be if that conception were true. In understanding critically each conception, the Pyrrhonist also understands something about the world if such a proposal correctly represented the way things are. Given that eventually Pyrrhonists suspend judgment about such proposals, they are not committed to their truth, but can perfectly coherently concede that the critical exploration of dogmatic proposals offers some understanding $3 / 40$ of the way things could be, even though it is unclear that we can know how they actually are. (Ultimately, the neo-Pyrrhonist suspends judgment about such knowledge claims.)

The move here is entirely analogous to the constructive empiricist's attitude toward rival interpretations of quantum mechanics (see VAN FRAASSEN, 1991). Although no commitment to the truth of any given interpretation of quantum theory is ever advanced, each interpretation is taken as providing some understanding. By examining the details of each interpretation, we understand various aspects of quantum mechanical objects and processes: how they emerge, which features they display, and why they behave the way they do $3 / 4$ in light of each interpretation. What we have is a form of pluralism, in which each interpretation contributes with a particular account of the overall picture, by indicating how things could be.

It is not claimed here that these dogmatic philosophies are true, or even approximately true. (It is unclear how such truth could be established.) The idea is simply that they can be true. Clearly, this is compatible with an agnostic attitude about such philosophies $3 / 4$ an attitude that is obviously found in Pyrrhonism. If one suspends judgment 
about whether a certain philosophical doctrine is true, on the grounds that one is unable to decide the truth-value of that doctrine, it follows, dialectically, that such a doctrine could be true, at least in principle. From the perspective of dogmatic philosophies, in this way agnosticism would be motivated. If the doctrine in question cannot even be true, a dogmatic reason would have it that no consistent commitment to it would be justified even in principle, and the doctrine could be safely rejected (or ignored).

These are, in outline, the central features of the non-dogmatic form of investigation implemented by neo-Pyrrhonists, and the more positive spin that can be offered by them on the exploration of empirical inquiry $3 / 4$ by highlighting the sort of understanding that is made possible by skeptical research. This exploration, however, is not restricted to philosophical doctrines. Scientific theories also offer a significant source of understanding $3 / 4$ of the way things could be if the scientific theories in question were true.

\section{Neo-pyrrhonism and constructive empiricism}

There are various common features between neo-Pyrrhonism and constructive empiricism. In what follows, I will highlight some of them.

(i) Underdetermination arguments. As noted already, a significant common feature between the constructive empiricist and the neo-Pyrrhonist stances is their use of underdetermination arguments. This style of argument, as we saw, is used to challenge the belief in certain unobservable entities in science $3 / 4$ or, at least, to challenge the need for the introduction of some such entities in the explanation of the phenomena. After all, the same phenomena can be successfully accounted for by radically different unobservable entities, as the case of the different interpretations of non-relativist quantum mechanics illustrates. Both in (neo-)Pyrrhonism and in constructive empiricism, underdetermination arguments play the same role. They offer considerations to the effect that it is unclear that we can decide what is really going on beyond the appearances, and hence these arguments motivate an agnostic attitude toward the unobservable. These arguments typically tend to be local in nature, exploring various forms of underdetermination (for instance, regarding specific theories and the evidence for them), rather than advancing global, all-encompassing considerations. In fact, Bas VAN FRAASSEN, 2007, tends to be skeptical about global forms of underdetermination arguments, clearly preferring to invoke local ones (see VAN FRAASSEN, 1980).

(ii) Belief in unobservable entities is not required to the investigation of the empirical world. As was just noted, this is a consequence of the use of underdetermination arguments. Both the skeptic and the constructive empiricist can explore different accounts of the empirical world without thereby being committed to the relevant unobservable entities. Of course, this leaves it open whether they should or should not believe in the phenomena. Constructive empiricists believe in them. In fact, they are realist about observable entities, taking them to exist (see VAN FRAASSEN, 1980). The issue, however, is somewhat more nuanced for (neo-)Pyrrhonists. On one interpretation, (neo-) Pyrrhonists have no beliefs whatsoever $3 / 4$ if beliefs are taken to be a commitment to the way things really are. On a weaker interpretation, however, skeptics do believe in the appearances, in the sense that it seems to them that something is so and so. But given that reports on the way things seem to be do not thereby commit skeptics to the ultimate nature of things, no trouble emerges for (neo-)Pyrrhonists, who are still not making claims about the unobservable (for further discussion of this issue, see the papers collected in BURNYEAT and FREDE (eds.), 1998).

(iii) Truth is not an aim of inquiry. For the constructive empiricist, the aim of science is not truth, but something weaker: empirical adequacy (VAN FRAASSEN, 1980). Roughly speaking, a scientific theory is empirically adequate if it offers a correct account of observable entities, events and processes, leaving it open whether it is true or not about the domain of the unobservable. Similarly, neo-Pyrrhonists do not take truth to be the aim of inquiry. Skeptics can try to find out the 
truth, but this seems to require eliminating rival, underdetermined alternative explanations, and it is unclear how to do that. Understanding emerges as an unexpected outcome of skeptical inquiry (in analogy with the way that ataraxia emerged for the Pyrrhonist; see SEXTUS EMPIRICUS, 1994), and establishing the truth $3 / 4$ that is, a literally true description of the world $3 / 4$ is not required for such understanding. After all, it seems that we can obtain understanding even when we are dealing with false accounts of the phenomena. For example, fictional works often provide understanding and insight about various aspects of human behavior, even though what is described in such works is not literally true. Similarly, for constructive empiricists, truth is not required to make sense of scientific practice. For instance, as noted, rival interpretations of quantum mechanics do provide understanding, even though presumably they cannot all be true, since they are mutually inconsistent. (It is typically assumed, by dogmatic philosophers, that the quantum world is not inconsistent, in the sense that inconsistent descriptions of that world cannot be true simultaneously. Of course, if disagreement emerges about this issue, the neo-Pyrrhonist will consider the various accounts on both sides of the divide and will end up suspending judgment about it.)

(iv) Critical assessment of metaphysics. There is an additional feature that brings neo-Pyrrhonism closer to a non-dogmatic form of empiricism. Empiricism has traditionally been associated with a critical attitude toward metaphysics (VAN FRAASSEN, 2002). Given that metaphysical inquiries typically posit entities beyond what can be directly experienced, the question arises as to how one can have knowledge of these entities. Underdetermination arguments are, once again, invoked to challenge the postulation of the objects in question, since radically different and incompatible accounts can be offered of the same phenomena. Similarly, Pyrrhonists are also critical of dogmatists' claims to know what goes on beyond the phenomena. Given the conflicting accounts offered by rival dogmatic conceptions, Pyrrhonists are unable do decide which of them (if any) is correct, which, in turn, leads to the suspension of judgment. Not surprisingly perhaps, we find here a similar attitude in both stances.

The neo-Pyrrhonist implements the critical response to metaphysics in terms of Agrippa's modes. Rather than a dogmatic rejection of metaphysical doctrines, we have in neo-Pyrrhonism a more nuanced suspension of judgment about the content of metaphysical doctrines regarding unobservable entities, processes, and events. The resulting agnostic attitude meshes very well with the historical mistrust that empiricists have shown toward metaphysics. However, given that no simple rejection of metaphysics is involved, but a critical exploration of various metaphysical doctrines, no form of dogmatism need to emerge in either case.

It should now be clear why the neo-Pyrrhonian attitude has much in common with constructive empiricism. However, the two stances are still significantly different. After all, constructive empiricism involves a particular doctrine about the aim of science (the search for empirically adequate theories rather than true ones), and as such, it incorporates beliefs that go beyond the phenomena. For example, the very concept of empirical adequacy, in the way van Fraassen characterizes it, involves reference to unobservable entities, such as models and isomorphic mappings (see VAN FRAASSEN, 1980, p. 64). Even if the concept of isomorphism can be expressed in a way that does not involve commitment to abstract entities (e.g., it can be formulated with the resources of a second-order language), the statement that a given scientific theory is empirically adequate involves reference to models $3 / 4$ namely, the empirical substructures of a given scientific theory (see VAN FRAASSEN, 1980, p. 64)3/4which are abstract entities, on the usual account.

However, perhaps this commitment can be avoided. Van Fraassen has pointed out (with QUINE, 1953) that 'Snow is white' is true only in virtue of snow being white, not in virtue of the existence of a universal, whiteness, to which snow bears some relation. He then continued: 
The same point applies to isomorphism. Let's take a particular case of a concrete physical, observable object: this table top is metrically isomorphic to a Euclidean square. That is true, but simply because this table top is square $3 / 4 c^{\prime}$ est tout! It is true because the top's sides are of equal length and the angles between them are right angles. It could be paraphrased as "the table top instantiates the Euclidean square Form", but the cash value of the assertion carries no metaphysical commitment: it is just that the table top is square (VAN FRAASSEN, 2008, p. 249).

The point is quite right in the case of concrete objects. However, it is not clear how exactly it can be extended when we are asserting that a given scientific theory is empirically adequate. For in this case, as opposed to what happens with a concrete object, the isomorphism connects two abstract structures: an empirical substructure (a structure from a given scientific theory that describes the relevant observable objects, processes, and events) and the surface model (the mathematical structure that represents the data that have been obtained empirically). Here we cannot say that the cash value of the assertion carries no metaphysical commitment, since we are asserting that two abstract objects have the same structure (that is, there is a one-to-one mapping between the empirical substructure and the surface models that preserves the relations in each of them). It seems that the constructive empiricist would still be committed to abstract entities by making such claim. (For some strategies to avoid this difficulty, see BUENO, 2021.)

Moreover, as noted, constructive empiricism also involves a (direct) realist view about observable entities, which are taken to exist in roughly the way we perceive them. This is, of course, the sort of philosophical doctrine about which the (neo-)Pyrrhonist suspends judgment. In fact, to follow the appearances is not the same as to adopt a realist view about the observable, given that the skeptic follows the appearances in a non-dogmatic way, that is, without making claims about the ultimate nature of such appearances. Neo-Pyrrhonists and constructive empiricists will clearly agree that observable objects exist. But when the former make this remark, they are simply reporting on what seems to be the case $3 / 4$ - no philosophical statement about what is going on is involved. Nothing prevents constructive empiricists from joining Pyrrhonists here. But this would require not being committed to a (direct) realist view about the observable, or, at least, reformulating direct realism in a non-dogmatic way.

Clearly, no doctrines about the aim of science, about the concept of empirical adequacy, or about the nature of the observable are found in neo-Pyrrhonism. From this point of view, it involves fewer commitments than constructive empiricism does.

\section{Pyrrhonism and scientific activity}

Sextus has engaged very thoroughly with the science and, of course, the philosophy of his time. The neo-Pyrrhonist does the same. In fact, as will become clear, moves very similar to those that Sextus has advanced can be invoked by the neo-Pyrrhonist in the examination of contemporary scientific practice.

It all starts with an attempt to answer scientific or philosophical questions. (In what follows, I will focus now on questions that bear on scientific practice.) It turns out that the answers to these questions go beyond the phenomena in that they postulate entities that are not directly observable. Not surprisingly, there is disagreement about which of these answers (if any) is ultimately correct. Thus, similarly to Sextus, neo-Pyrrhonists start by considering the ubiquitous disagreement that emerges in scientific practice when one tries to settle issues that go beyond the phenomena. Some examples will illustrate certain moves that are involved.

Suppose that the issue concerns the nature of the fundamental constituents of the physical world: are they particles or some other kind of thing (such as fields)? Neo-Pyrrhonists will point out that there is, in fact, disagreement about this issue. If one adopts the account provided by non-relativistic quantum mechanics (in one of its interpretations), the world is ultimately constituted by particles (even though the latter can display, in some contexts, a peculiar wave-like behavior). However, if one adopts the account advanced in quantum field theory, the fundamental components of reality are ultimately fields 
rather than particles $3 / 4$ and a significantly different ontology emerges. Given that both theories have been equally successful in their empirical predictions $3 / 4$ in fact, impressively so $3 / 4$ it is unclear how they can be chosen on empirical grounds. But without making such a choice, it is unclear what the answer to the initial question about the fundamental constituents of the physical world ultimately is.

It may be argued that we can choose between the two theories (non-relativistic quantum mechanics and quantum field theory) in terms of methodological criteria, such as simplicity or explanatory power. Let us consider each of them in turn. Regarding simplicity, clearly there is significant disagreement about what simplicity in fact is. Is it a matter of a theory displaying fewer equations, advancing equations that are more computationally tractable than the rival theory, or introducing fewer kinds of entities? These are significantly different criteria for simplicity, and depending on the criterion that is adopted, one theory may be counted as simpler than its rival (e.g., because it advances equations that are more computationally tractable, such as Schrödinger's equation), but it may be counted as more complex according to a different criterion (given that, say, it introduces a greater number of different kinds of entities, such as particles and waves). Given that assessments of simplicity seem to depend on the criterion that is adopted, we now seem to face a methodological disagreement about rival conceptions of simplicity. How can such a methodological disagreement be settled? It would not be plausible simply to assume (without argument) one of the rival accounts of simplicity, given that, in this case, a contrary account could be equally assumed by the rival party. Moreover, it is also possible that even if a particular criterion of simplicity is adopted by all the parties, the scientific theories under consideration turn out to be equally simple (or equally complex) with respect to that criterion, in which case the latter will fail to select one of the theories.

Similar considerations apply to the concept of explanatory power. There is also significant disagreement as to what explanatory power ultimately is. Some accounts insist that explanatory considerations should identify the relevant causal processes involved in the events in question, while other proposals emphasize the connections between explanation and unification, while other views insist that explanation is ultimately a matter of pragmatics, of the way in which certain bits of information are used (in particular, on such views, it is possible for a false theory to be explanatory). These are significantly different conceptions of explanatory power, and depending on the conception that is adopted, one theory may be considered as being more explanatory than its rival (e.g., because it identifies the relevant causal processes involved, such as particles and waves), but it may be counted as less explanatory according to a different conception (given that, say, it offers a less unified account of the phenomena in question, since it involves both particles and waves rather than only fields). Given that assessments of explanatory power seem to depend on the criterion that is adopted, we now seem to face a methodological disagreement about rival conceptions of explanatory power. How can such a methodological disagreement be settled? It would not be plausible simply to assume (without argument) one of the rival accounts of explanatory power, given that, in this case, a contrary account could be equally assumed by the rival party. Furthermore, it is also possible that even if a particular conception of explanatory power is adopted by all the parties, the scientific theories under consideration turn out to be equally explanatory (or equally non-explanatory) with respect to that conception, in which case the latter will fail to select one of the theories.

If the criteria of simplicity and explanatory power do not seem to offer unique answers to the question of how one can choose between rival, but empirically adequate, theories of the ultimate constituents of the world, neo-Pyrrhonists are unable to decide the issue, and suspend judgment. (For further critical discussion of the role of theoretical utility arguments in metaphysics, see BUENO and SHALKOWSKI, 2020.)

Note, however, that even if somehow the disa- 
greement about the ultimate constituents of the world was settled (and so the issue of whether such constituents are particles or fields, e.g., is decided), the nature of the corresponding entities would not be thereby settled. After all, the issue would still emerge as to whether such fundamental constituents are individuals (entities for which there are well defined identity and individuation conditions) or non-individuals (things for which no such conditions can be specified). These are dramatically different accounts of the nature of the fundamental ontology, and both turn out to be compatible with fundamental physics (see FRENCH and KRAUSE, 2006). The point is particularly clear in the case of non-relativist quantum mechanics, but even in quantum field theories related worries emerge.

Once again, given the disagreement in question, and the fact that the different answers turn out to be all empirically adequate, it is unclear how to choose between the rival conceptions on empirical grounds. One could try to choose, once again, based on methodological considerations. Nevertheless, for the reasons just discussed, it is unclear to what extent this move is likely to succeed. Being unable to decide the issue, neo-Pyrrhonists suspend judgment.

It may be thought that neo-Pyrrhonists are simply considering easy cases, since there have always been deep disagreements about the foundations of physics. Would the situation be different if we consider instead experimental physics? It turns out that even there we find disagreement. Consider, for example, the question of what the shape of an atom is. Are atoms spherical, or do they have a conic structure (or some other shape altogether)? Clearly, in order to answer this question, we need to use relevant scientific instruments (in this case, different kinds of microscopes), given that atoms cannot be seen with the naked eyes. It turns out, nonetheless, that there is disagreement here. Depending on the instruments that are used, and on the convention codes that are adopted for the visual presentation of the resulting images, we obtain dramatically different answers to the question. For example, some images generated by a scanning tunneling microscope represent atoms as having a conic structure. Other images generated by the same instrument, however, employ different convention codes, and given these codes, atoms are represented as spherical. How can we determine which of these representations (if any) is correct, since any access we have to atoms is always mediated by the relevant instruments? It is simply not clear how one can choose between these conflicting representations. Given that the representations offer incompatible accounts of the shape of atoms, at most one of them is correct (assuming, for the sake of argument, that the shape of atoms is something consistent). Clearly, it would not be persuasive simply to assume one of the representations as being correct; one would need to offer some reasons for the choice. But what arguments could be given? Without any direct access to atoms (that is, a non-instrumentally mediated access to them), we do not seem to have a suitable criterion to determine the adequacy of rival representations. As a result, it is just not clear how to determine what the shape of an atom is. Not surprisingly, neo-Pyrrhonists suspend judgment about the issue.

It may be argued that we have these kinds of disagreement because we are dealing with empirical aspects of the world, whether these aspects concern theoretical issues (e.g., about the nature of the fundamental constituents of the universe) or whether they raise experimental issues (for instance, about the shape of atoms). Would the picture change if we consider non-empirical issues, such as those that are examined in mathematics? I do not think it would.

As an illustration, suppose we are trying to determine the nature of mathematical objects. Once again, neo-Pyrrhonists will point out that there is disagreement about this issue. A Fregean will insist that arithmetical objects are of a particular type that is characterized in terms of only the logical vocabulary plus definitions (see, e.g., FREGE, 1980). So, given that no object falls under the concept non-self-identical, zero is the number of objects that fall under that concept. 
Given that only one object falls under the concept identical to zero, one is the number of objects that fall under that concept. Given that exactly two objects fall under the concept identical to zero or one, two is the number of objects that fall under that concept. In this way, arithmetic can be ultimately constructed in terms of second-order logic and definitions. We have here a platonist account of the nature of mathematical objects.

But nominalists offer a significantly different conception. Consider, for instance, a modal-structural interpretation (HELLMAN, 1989). On this account, each true mathematical statement $S$ (say, about arithmetic) is translated into two modal statements: One states that if there were arithmetical structures of the appropriate kind (e.g., structures satisfying the axioms of Peano Arithmetic), $S$ would be true in these structures. The other states that the structures of the relevant kind are possible. Clearly, we do not have here a commitment to either the existence of mathematical objects or to the mathematical structures in question. The view is ultimately agnostic about both. Only the possibility of certain structures is invoked. On this conception, the nature of mathematical objects is thought to be significantly different from the Fregean view, given that not even the existence of such objects is required.

How can one choose between these two conceptions? It turns out that it is not clear how to do so. The platonist conception has the advantage of being able to take mathematical discourse literally, so that when mathematicians say that there are infinitely many prime numbers, what they say is true in virtue of there being such numbers. But some account is then needed of how we have knowledge of these numbers, given that they are abstract (and thus are not located in space-time nor are causally active). Platonists, including Fregeans, have of course developed various strategies to address this issue, but so far none of them seems to be unproblematic (see, e.g., BALAGUER, 1998, and BUENO, 2011). Nominalists, in turn, do not face the epistemological problems that have plagued Platonism. But they are typically unable to take mathematical discourse literally, given the need to rewrite mathematical discourse (e.g., in the way the modal-structuralist does) in order to avoid ontological commitment to mathematical entities. AZZOUNI, 2004, offers the best available nominalist alternative, and his proposal seems to be able to accommodate mathematical discourse literally. However, some worries arise about the notion of reference that is invoked (see BUENO and ZALTA, 2005, and AZZOUNI, 2009, for a response, and BUENO, 2013b, for additional concerns).

So, both platonism and nominalism have significant benefits, but they also face considerable difficulties. In a somewhat unexpected way, they seem to be equally persuasive. Not because they provide equally adequate accounts, but because what is a difficulty for one view (such as the epistemological problem) is a benefit for the other (since it does not face that problem), and what is a benefit for one proposal (such as the ability to take mathematical discourse literally) is a problem for the other (due to its inability to do that). Given that the views are incompatible $3 / 4$ one affirms that mathematical objects exist, the other denies that $3 / 4$ they cannot be consistently combined. Being unable to decide between them, neo-Pyrrhonists suspend judgment.

These considerations offer, of course, only an illustration of the sort of investigation that neo-Pyrrhonists implement as part of the engagement with contemporary science and its philosophy. But they should indicate the flavor and the general tone of this inquiry.

It may be asked whether there is an account of scientific knowledge underlying the neo-Pyrrhonian stance. Clearly, neo-Pyrrhonists, similarly to Pyrrhonists, do not take knowledge in a dogmatic way, that is, in terms of establishing claims about the world (particularly about its unobservable portions). Knowledge, it may be thought, is something that emerges from a certain practice of investigation (the skeptical practice), in a non-dogmatic way. Clearly the skeptic is concerned with the practical outcomes of such knowledge, by being able to control relevant phenomena, and explore technological applications that can be developed. But perhaps neo-Pyrrhonists can also offer something that goes beyond the practical applications alone, 
and engage with the epistemological dimension as well (see PORCHAT PEREIRA, 2006)?

Neo-Pyrrhonists record the understanding offered by the skeptical investigation, since this inquiry explores multiple ways of answering a given question, e.g., about the nature of numbers, the shape of atoms, or some features of the ultimate constituents of the world. We obtain an understanding of the various possibilities that are available to make sense of the issues under consideration, and the insights such possibilities offer $3 / 4$ even if neo-Pyrrhonists are unable in the end to decide which of them (if any) is ultimately correct. Furthermore, by indicating why they are unable to decide the issues, at least at the present moment, neo-Pyrrhonists also help us to understand why suspension of judgment emerges, and why, given the circumstances, this is a perfectly natural state to be in. Due to the deep conceptual disagreement surrounding all these issues, and the (relative) equal force of the alternative accounts on offer, suspension of judgment seems to be expected.

For neo-Pyrrhonists, understanding emerges from the skeptical strategy of investigation. By contrasting rival accounts of the phenomena, and assessing their strengths and weaknesses, skeptics gain understanding of the world, at least of how it could be. These remarks clearly do not provide a characterization of empirical knowledge. Any such characterization would only yield another philosophical account to be criticized by the skeptic. The remarks only describe a non-dogmatic way of thinking about empirical knowledge: a skeptical, neo-Pyrrhonian way.

\section{Conclusion}

As the considerations made so far suggest, it is possible to sketch, within the constraints of a neo-Pyrrhonist stance, a positive description of some aspects of foundational inquiry (see also PORCHAT PEREIRA, 2006). Of course, the idea is not to provide necessary and sufficient conditions for knowledge. (It is unclear whether any such conditions can be offered anyway.) Rather, the project consists in exploring a skeptical attitude toward empirical knowledge, indicating the sort of information about the empirical world that can be obtained $3 / 4$ and the understanding that emerges from the investigation $3 / 4$ without making assertions about the truth of what goes on beyond the phenomena.

\section{Acknowledgements}

This paper was inspired by the fascinating philosophical stance developed by Oswaldo Porchat Pereira, and by many discussions with him. The work explores ideas that Porchat has clearly articulated (see PORCHAT PEREIRA, 2006) and is dedicated to his memory with great respect and affection. His friendship and encouragement meant the world to me, and he is sorely missed. Porchat would not have agreed with every detail of what is advanced here, but disagreement is the beginning of any skeptical investigation $3 / 4$ even among skeptics! Many thanks are also due to Diego Machuca, Plínio Smith, and Michael Williams for very helpful comments and suggestions.

\section{References}

AZZOUNI, J. Deflating Existential Consequence: A Case for Nominalism. New York: Oxford University Press, 2004.

AZZOUNI, J. Empty de re Attitudes about Numbers Philosophia Mathematica, [S. I.], n. 17, p. 163-188.

BUENO, O. Logical and Mathematical Knowledge. In: S BERNECKER; D. PRITCHARD (ed.). Routledge Companion to Epistemology. London: Routledge, 2011. p. 358-368.

BUENO, O. Disagreeing with the Pyrrhonist? In: D. MACHUCA (ed.). Disagreement and Skepticism. New York: Routledge, 2013a. p. 24-45.

BUENO, O. Nominalism in the Philosophy of Mathematics. In: ZALTA, E. N. (ed.). Stanford Encyclopedia of Philosophy (Fall 2013 edition). 2013b. Disponivel em: http://plato.stanford.edu/archives/fall2013/entries/ nominalism-mathematics.

BUENO, O. Structural Representation and the Ontology of Models. In: CASSINI, A.; REDMOND, J. (ed.). Models and Idealizations in Science: Artifactual and Fictional Approaches. Cham: Springer, 2021. p. 199-216.

BUENO, O.; SHALKOWSKI, S. Troubles with Theoretical Virtues: Resisting Theoretical Utility Arguments in Metaphysics. Philosophy and Phenomenological Research, [S. I.], n. 101, 2020. p. 456-469.

BUENO, O.; ZALTA, E. A Nominalist's Dilemma and its Solution. Philosophia Mathematica, [S. I.], n. 13, 2005. p. 294-307.

BARNES, J. The Toils of Scepticism. Cambridge: Cambridge University Press, 1990. 
BALAGUER, M. Platonism and Anti-Platonism in Mathematics. New York: Oxford University Press, 1998.

BURNYEAT, M.; FREDE, M. (ed.). The Original Sceptics: A Controversy. Indianapolis: Hackett Publishing Company, 1998.

FOGELIN, R. Pyrrhonian Reflections on Knowledge and Justification. New York: Oxford University Press, 1993.

FREGE, G. The Foundations of Arithmetic. Translated by J. L. Austin. Oxford: Blackwell, 1980.

FRENCH, S.; KRAUSE, D. Identity in Physics: A Historical, Philosophical, and Formal Analysis. Oxford: Clarendon Press, 2006.

HELLMAN, G. Mathematics without Numbers. Oxford: Clarendon Press, 1989

MACHUCA, D. Pyrrhonism Past and Present: Inquiry, Rationality, and Disagreement. Cham: Springer, 2022.

PORCHAT PEREIRA, O. Rumo ao Ceticismo. São Paulo: UNESP, 2006.

QUINE, W. V. On What There Is. In: QUINE, W. V. From a Logical Point of View. Cambridge, MA: Harvard University Press, 1953. p. 1-19.

SEXTUS EMPIRICUS. Outlines of Scepticism. Translated by Julia Annas and Jonathan Barnes. Cambridge: Cambridge University Press, 1994.

SMITH, P. (ed.). O Neopirronismo de Oswaldo Porchat: Interpretações e Debates. São Paulo: Alameda, 2014.

SMITH, P. Uma Visão Cética do Mundo: Porchat e a Filosofia. São Paulo: UNESP, 2017.

SMITH, P. Sextus Empiricus's Neo-Pyrrhonism: Skepticism as a Rationally Ordered Experience. Cham: Springer, 2022.

VAN FRAASSEN, B. C. The Scientific Image. Oxford: Clarendon Press, 1980.

VAN FRAASSEN, B. C. Laws and Symmetry. Oxford: Clarendon Press, 1989.

VAN FRAASSEN, B. C. Quantum Mechanics: An Empiricist View. Oxford: Clarendon Press, 1991.

VAN FRAASSEN, B. C. The Empirical Stance. New Haven: Yale University Press, 2002.

VAN FRAASSEN, B. C. From a View of Science to a New Empiricism. In: B. Monton (ed.). Images of Empiricism: Essays on Science and Stances, with a Reply from Bas C. van Fraassen. Oxford: Oxford University Press, 2007.

VAN FRAASSEN, B.C. Scientific Representation: Paradoxes of Perspective. Oxford: Clarendon Press, 2008.

\section{Otávio Bueno}

Ph.D. in Philosophy, University of Leeds, UK; MA in Philosophy, University of São Paulo, São Paulo, SP, Brazil. Professor of Philosophy at the University of Miami, Department of Philosophy, Cooper Senior Scholar in Arts and Sciences, Editor in Chief of Synthese.

\section{Mailing Adress}

\section{Otávio Bueno}

University of Miami

Department of Philosophy

Coral Gables, FL 33124-4670, USA

Os textos deste artigo foram conferidos pela Poá Comunicação e submetidos para validação do autor antes da publicação. 